\title{
Recurrent Epstein-Barr Virus-Associated Lymphoproliferative Disease with Primary Immunodeficiency
}

National Cancer Institute

\section{Source}

National Cancer Institute. Recurrent Epstein-Barr Virus-Associated Lymphoproliferative

Disease with Primary Immunodeficiency. NCI Thesaurus. Code C160151.

The reemergence of Epstein-Barr virus-associated lymphoproliferative disease with primary immunodeficiency after a period of remission. 